\title{
Investigation of GSM Signal Strength in Rural Communities in the South-Eastern Region of Nigeria
}

\author{
R. C. Okoro, \\ P. C. Iwuji, \\ Electronics and Computer Unit, Department of Physics, \\ University of Calabar, Nigeria
}

Doi: 10.19044/esj.2019.v15n15p140 URL:http://dx.doi.org/10.19044/esj.2019.v15n15p140

\begin{abstract}
This paper focuses on the investigation of GSM networks' signal strength coverage in rural communities in the South-Eastern region of Nigeria. The Network Cell Info Lite application installed in two Gionee M5 phones was used to carry out measurement of the signal strength received from the transmitting stations of various GSM networks. Signal strength obtained from the application was compared with the Gionee android inbuilt signal meter for authentication purposes. The signal strength measurements were conducted in Amaigbo from $18^{\text {th }}$ August to $26^{\text {th }}$ August 2018, Uli from $29^{\text {th }}$ August to $6^{\text {th }}$ September 2018 and Amasa from $8^{\text {th }}$ September to $16^{\text {th }}$ September 2018, all in South-Eastern region of Nigeria. The data obtained was analyzed to determine the GSM networks coverage levels, the availability of the networks, and the quality of the network provided in the aforementioned rural communities. The result of the study shows that most rural communities in the South-East region of Nigeria, like Amaigbo and Amasa, experiences a lot of periods of out of service as a result of poor network coverage level. It was also observed that in some rural communities in the east with high population density such as Uli, the network coverage level is relatively high. Thus, quality network services were recorded in Uli. It is therefore recommended that more booster stations be sited to enhance good network coverage level in rural communities within the South-Eastern region of Nigeria.
\end{abstract}

Keywords: GSM Network, Signal Strength, Coverage Level, Services, Transmitting

\section{Introduction}

The introduction of cellular phones in Nigeria has allowed millions of Nigerians in urban and rural areas to be more connected than ever. Prior to 
the introduction of the Global System Mobile (GSM) telecommunication, Nigerians depended on the use of an automobile to commute between communities with a view to disseminating information (Olawole, 2013). GSM has been described as the major dividend of Nigeria's evolution to democracy. This is due to the positive influence of GSM on the socioeconomic development of the nation. However, GSM telecommunication is not without any challenge as in the past three years or more, there has been an enormous public uproar over the declining quality of service in the running of GSM enterprises (Ndukwe, 2006). Hence, this gave rise to the second generation $(2 \mathrm{G})$ of cellular telephones networks. This network can now carry more subscribers as against the analogue systems (Kuboye, Alese, Fajuyigbe \& Adewale, 2011).

GSM signal proficiency and network quality assessment are critical steps for cellular telecommunication facilitators, as the profits spawned and client gratification is unswervingly related to the GSM signal quality and performance. GSM signal evaluation, most significantly from the customer's point of view, is essential to assess the signal quality and sustain a standard quality of service (Nkordeh, Olatunbosun, Bob-Manuel \& Oni, 2016). GSM signal which is also known as service and reception is the signal received by a phone from a network on the communication pathway. The GSM signal varies due to some factors such as the height of the antenna, transmitter power, nearness to the transmitting antenna, and obstructions like trees or buildings (Iwuji \& Emeruwa, 2018). Most cellular phones use bars of increasing height to show the estimated strength of a received signal to the cell phone user. Usually, five bars are used to indicate the signal strength on most cell phones.

The numbers of bars on the cell phone is not always the best means to measure mobile phone signal strength. This is because the mobile phone signal is subjective across all carriers. Mobile phone signals are radio waves that operate within a definite frequency. The cell phone signals operate within the range of $-50 \mathrm{dBm}$ to $-120 \mathrm{dBm}$ (Bablu, Heena, Aswathy \& Komal, 2017). A signal of $-120 \mathrm{dBm}$ is a dead zone or an extremely poor signal. This is applicable to all mobile devices both in Nigeria and other countries. Thus, measurement in $\mathrm{dBm}$ and not the number of bars on the phone is the best way to know the accurate strength of the signal on a cell phone. The signal strength of about -50 to $-79 \mathrm{dBm}$ ( 4 - 5 bars) outside an enclosed place is generally considered to be a very strong signal strength. Good signal strength ranges from -80 to $-89 \mathrm{dBm}(3-4)$. Signal strength within the range of -90 to -99 $\mathrm{dBm}(2-3$ bars $)$ are regarded as average signal and those within the -100 to $-109 \mathrm{dBm}(1-2$ bars $)$ are considered to be poor signals. Very poor signals are signal strength within the range of -110 to $-120 \mathrm{dBm}(0-1 \mathrm{bar})$ (Bablu, Heena, Aswathy \& Komal, 2017). This implies that stronger signal strength 
for mobile phones are recorded when the signal strength of the device approaches zero (0). Generally, from $-95 \mathrm{dBm}$ and above, the signal strength is considered to be below average. However, from $100 \mathrm{dBm}$ and above, the signal strength of the cell phone experiences some serious inconsistent service and weak signal reception (Elechi \& Otasowie, 2015). The mobile phone signal booster will struggle with signal strength above $105 \mathrm{dBm}$. A numerical value proportional to the received signal strength measured by the cell phone is known as the Arbitrary Strength Unit (ASU). The actual signal strength measured in $\mathrm{dBm}$ can be calculated by using a specific formula. However, the formula used to estimate the actual signal obtained in $\mathrm{dBm}$ differs for 2G, 3G, and 4G networks (Onwuemele, 2011).

Information dissemination by individuals within the country, states, and local government areas are mostly carried out with the aid of GSM. This is done through a voice call, electronic mail, short message service (SMS), and watching of informative movies or electronic learning (Emeruwa, 2015). In some of these areas (especially in rural communities), effective and efficient dissemination of this information is not totally achieved. This may be due to average, poor or no signals, interference, obstruction, and congestion within the area. Thus, the main purpose of this research is to investigate the signal strength of GSM networks in rural communities within the South-Eastern states of Nigeria.

\section{Study Location}

The investigation of GSM signal strength in rural communities was carried out in three different states of South East, Nigeria. The rural communities are Amaigbo in Nwangele LGA of Imo State, Uli in Ihiala Local Government Area (LGA) of Anambra State and Amasa in Ohafia LGA of Abia State. The signal strength of Airtel, Globacom, 9Mobile and MTN networks was critically examined in these three locations from $18^{\text {th }}$ August 2018 to $15^{\text {th }}$ September 2018.

Amaigbo is the capital of Nwangele Local Government Area in Imo State. It is located at Latitude $5^{\circ} 43^{\prime} \mathrm{N}$ and longitude $7^{\circ} 45^{\prime} \mathrm{E}$. It is one of the largest towns in Imo State, Nigeria with a population of more than 50,000 people. The name of the villages recognized by the authority of council in Amaigbo are, Ubahu, Umuanu, Umuduruma na Obodo, Nnenano, Umutakwu, Umuenwere, Umuchoke, Nnanato, Umuezeobolo, Ofeahia/Kabia, Nnanto. The people of Amaigbo two are mostly farmers and civil servants (Ndukwu, Onweremadu, Nkwopara, Ahukaemere, Ihem and Agim, 2015). Amaigbo houses two higher institutions which are the College of Health Umuanu, Amaigbo and Imo State School of Nursing (S.O.N.), St. Mary's Hospital, Amaigbo. 
Uli is a town in Ihiala Local Government in Anambra State, Nigeria. Its geographical coordinates are $5^{\circ} 47^{\prime} \mathrm{N}$ and $6^{\circ} 52^{\prime} \mathrm{E}$. The villages in Uli are Amaputu, Idinwanedo, Ihite, Ndirokwo, Ndiumereaku, Ubahudara, Umaku, Umuabuchi, Umubazu, Umuchima, Umuezike, Umuoma and Uziama. The people of Uli are predominantly petty traders and farmers (Onyido, Obinatu, Umeanaeto, Obiukwu and Egbuche, 2011). It is the home of Anambra State University, Uli Campus, with a population of about 98,000 people (NPC 2006).

Amasa is a town in Ohafia LGA of Abia State, South East Nigeria. It is situated at Latitude $5^{\circ} 26^{\prime} \mathrm{N}$ and Longitude $7^{\circ} 55^{\prime} \mathrm{E}$. Amaogwuawa, Amapu, Amazo, Ibeku, Mbutunta, Umuagwu, Umuihima, Umuihioma, Umuiimo osisiasa, Umuimo, Umuimo - Egbelu and Umuobasi are the villages located in Amasa. Amasa has a population of about 38,000 people (1991, NPC).

\section{Material and Methodology}

The signal strengths of GSM networks considered in the research was monitored with the aid of a Network Cell Info Lite application installed in two Gionee M5 phones. The purpose of using two Gionee phones was to measure simultaneously the signal strength of the three networks so as to obtain a fair result. The received signal strength obtained from the application was compared with the Gionee android inbuilt signal strength meter to ascertain the accuracy of the Network Cell Info Lite Application. Network Cell Info Lite is a mobile network measurement and monitor tool for 4G Long-Term Evolution ( $\boldsymbol{L T E}), 4 \mathrm{G}+$, Wideband Code Division Multiple Access (WCDMA), Code Division Multiple Access (CDMA), and GSM. The application can also provide $\mathrm{WiFi}$ information. It has a two-signal meter gauge that displays both the cellular and WiFi signal strength level. The Network Cell Info Lite supports dual SIM except for mobile device with android less than 5.0, due to device/android limitation. It is capable of measuring signal strength received in decibel (milli watts). The application has the necessary facility to specify the actual network whose signal strength is being measured. Thus, extreme care was taken to avoid recording the signal strengths of a different network in place of the network being measured at a particular time. 


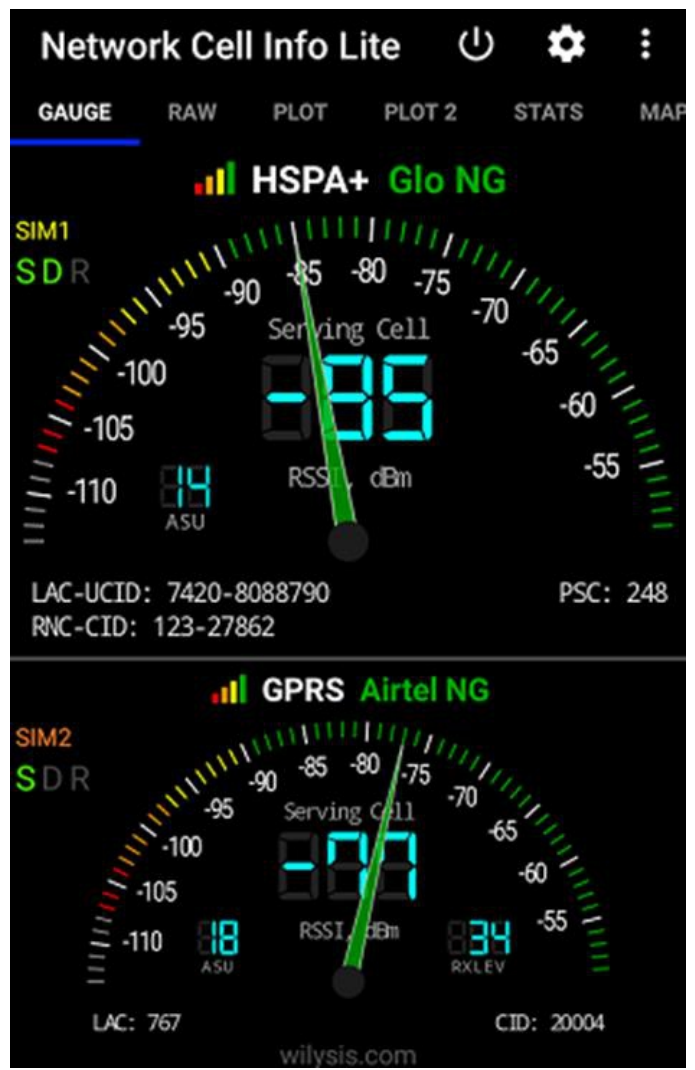

Picture 1. A screen shot of the Network Cell Info Lite $\leftarrow$ SIM status

Network

Glo NG

Signal strength

.77 dem 14 asu

Cellular network type

HSPAt

Service state

in senvice

Roaming

Not rosming

Cellular network state

connected

My phone number

Untonom

Picture 2. Inbuilt android signal strength metre 


\section{Measurement Procedure}

The signal strength of Airtel, Glo, 9Mobile and MTN networks were carefully measured at a choice location of the villages within the study location. The measurement was carried out daily for eight (8) consecutive days in all the villages in each of the town of the signal study. Signal strength measurement was carried out at a central location in villages within Amaigbo in Nwangele LGA of Imo State from 18 August to 26 ${ }^{\text {th }}$ August 2018, in villages located within Uli in Ihiala LGA of Anambra State between $29^{\text {th }}$ August and $6^{\text {th }}$ September 2018, and signal strengths of the GSM network under investigation in Amasa in Ohafia LGA of Abia State was measured between $8^{\text {th }}$ to $16^{\text {th }}$ September 2018. The measurement location was visited twice daily - morning and evening within the specified period. The measurement of the understudied networks was carried out simultaneously at each location. This was aimed at providing equality of test conditions. The average of the data obtained in each location within the period of measurement was recorded and analyzed using a statistical graph.

\section{Result and Discussion}

The investigation to determine the signal strength of GSM networks was radially carried out in villages within Amaigbo, Uli, and Amasa towns all in South-East, Nigeria. The investigation was carried out at a central position in each village within a specific time. The result obtained from the investigation is tabulated as shown in the table 1 below.

Table 1. Average signal strength values in $\mathrm{dBm}$ of the GSM networks investigated in villages located at Amaigbo in Nwangele L.G.A. of Imo State from $18^{\text {th }}$ August to $26^{\text {th }}$

August 2018

\begin{tabular}{|l|c|c|c|c|}
\hline \multirow{2}{*}{ Locations } & \multicolumn{4}{|c|}{ Signal Strength (dBm) } \\
\cline { 2 - 5 } & Airtel & Glo & MTN & 9Mobile \\
\hline Ubahu & -109 & -103 & -111 & -109 \\
\hline Umuanu & $-\mathbf{8 9}$ & -92 & -87 & -102 \\
\hline Umuduruma na Obodo & -103 & -102 & -89 & -106 \\
\hline Nnenano & -107 & -100 & -103 & -118 \\
\hline Umutakwu & -107 & -102 & -97 & -109 \\
\hline Umuenwere & -98 & -105 & -98 & -102 \\
\hline Nnanato & -102 & -105 & -99 & -107 \\
\hline Umuezeobolo & -105 & -88 & -88 & -82 \\
\hline Ofeahia/Kabia & -101 & -100 & -99 & -106 \\
\hline Nnanto & -109 & -107 & -101 & -106 \\
\hline
\end{tabular}


Table 2. Average signal strength values in $\mathrm{dBm}$ of the GSM networks investigated in villages located at Uli in Ihiala L.G.A. of Anambra State from $29^{\text {th }}$ August to $6^{\text {th }}$

September 2018

\begin{tabular}{|l|c|c|c|c|}
\hline \multirow{2}{*}{ Locations } & \multicolumn{4}{|c|}{ Signal Strength (dBm) } \\
\cline { 2 - 5 } & Airtel & Glo & MTN & 9Mobile \\
\hline Amaputu & -87 & -91 & -57 & -66 \\
\hline Idinwanedo & -77 & -99 & -104 & -91 \\
\hline Ihite & -69 & -97 & -107 & -96 \\
\hline Ndirokwo & -89 & -99 & -89 & -83 \\
\hline Ndiumereaku & -93 & -65 & -84 & -79 \\
\hline Ubahudara & -101 & -74 & -103 & -99 \\
\hline Umaku & -97 & -89 & -88 & -92 \\
\hline Umuabuchi & -87 & -87 & -64 & -78 \\
\hline Umubazu & -87 & -81 & -104 & -99 \\
\hline Umuchima & -97 & -93 & -109 & -82 \\
\hline Umuezike & -56 & -81 & -84 & -57 \\
\hline Umuoma & $-\mathbf{6 1}$ & -76 & $-\mathbf{6 2}$ & $-\mathbf{5 8}$ \\
\hline Uziama & -57 & -87 & -89 & -59 \\
\hline
\end{tabular}

Table 3. Average signal strength values in $\mathrm{dBm}$ of the GSM networks investigated in villages located at Amasa in Ohaofia L.G.A. of Abia State from $8^{\text {th }}$ September to $16^{\text {th }}$

September 2018

\begin{tabular}{|l|c|c|c|c|}
\hline \multirow{2}{*}{ Locations } & \multicolumn{4}{|c|}{ Signal Strength (dBm) } \\
\cline { 2 - 5 } & Airtel & Glo & MTN & 9Mobile \\
\hline Amaogwuawa & -97 & -82 & -77 & -96 \\
\hline Amapu & -102 & -87 & -103 & -97 \\
\hline Amazo & -96 & -99 & -91 & -96 \\
\hline Ibeku & -73 & -88 & -85 & -89 \\
\hline Mbutunta & $-\mathbf{8 9}$ & -81 & -95 & -89 \\
\hline Umuagwu & -97 & -102 & -81 & -101 \\
\hline Umuihima & -102 & -105 & -109 & $-\mathbf{- 1 1 1}$ \\
\hline Umuihioma & -105 & -107 & -71 & -98 \\
\hline Umuiimo-osisiasa & -81 & -100 & -88 & -88 \\
\hline Umuimo & -105 & -103 & -61 & -109 \\
\hline Umuimo- Egbelu & -107 & -120 & -77 & -111 \\
\hline Umuobasi & -97 & -104 & -87 & -106 \\
\hline
\end{tabular}

A location is said to have a good signal strength level, according to the international standard of Radio Signal Strength Level (RSSL), if the signal strength received in $\mathrm{dBm}$ is greater than $-90 \mathrm{dBm}$ (Bablu, Heena, Aswathy, \& Komal, 2017; Omorogiuwa, 2015). The coverage level (CL) in \% and average signal strength level (SSL) in $\mathrm{dBm}$ obtained from each measurement location of the different GSM network studied can be calculated from equations (i) and (ii) respectively.

$$
\begin{aligned}
& \mathrm{CL}=\frac{\mathrm{NSLGC}}{\mathrm{TNSL}} \times 100 \% \\
& \text { Average SSL }=\frac{\Sigma S \mathrm{SL}}{\mathrm{N}}
\end{aligned}
$$


Where, $\mathrm{N}=$ the number of signal strength level measured

NSLGC $=$ the number of study locations with good coverage and

TNSL $=$ the total number of study locations.

$\mathrm{SSL}=$ the signal strength level.

Analysis of Signal Strength Level obtained at Amaigbo in Nwangele L.G.A., of Imo State, South-East from $18^{\text {th }}$ August to $26^{\text {th }}$ August, 2018.

From Table 1, the total number of study locations in Amaigbo (TNSL) is 10. The number of study locations with good coverage (NSLGC) for Airtel network within the period of signal strength measurement is 1 , Glo network is 1, MTN is 3, and 9mobile is 1 .

Thus, Coverage Level for Airtel Network $=\frac{1}{10} \times 100 \%=10 \%$

Coverage Level for Glo Network $=\frac{1}{10} \times 100 \%=10 \%$

Coverage Level for MTN Network $=\frac{3}{10} \times 100 \%=30 \%$

Coverage Level of 9 mobile $=\frac{1}{10} \times 100 \%=10 \%$

Therefore, the coverage level of Airtel, Glo, MTN, and 9mobile networks are $10 \%, 10 \%, 30 \%$ and $10 \%$ respectively.

Analysis of Signal Strength Level obtained at Uli in Ihiala L.G.A., of Anambra State, South-East Nigeria from $29^{\text {th }}$ August to $6^{\text {th }}$ September, 2018.

The total number of study locations (TNSL) in Uli is 13. The number of study locations with good coverage (NSLGC) for Airtel network within the period of signal strength measurement is 9 , Glo network is $8, \mathrm{MTN}$ is 8 , and 9 mobile is 7 as shown in Table 2.

Thus, Coverage Level for Airtel Network $=\frac{9}{13} \times 100 \%=69 \%$

Coverage Level for Glo Network $=\frac{8}{13} \times 100 \%=62 \%$

Coverage Level for MTN Network $=\frac{8}{13} \times 100 \%=62 \%$

Coverage level of 9Mobile Network $=\frac{8}{13} \times 100 \%=62 \%$

Thus, the coverage level (in percentage) of Airtel, Glo, MTN, and 9mobile networks are $69 \%, 62 \%, 62 \%$, and $54 \%$ respectively. 


\section{Analysis of Signal Strength Level obtained at Amasa in Ohaofia L.G.A., of Anambra State, South-East Nigeria from $8^{\text {th }}$ to $16^{\text {th }}$ September 2018.}

The total number of study locations (TNSL) in Amasa is 12. The number of study locations with good coverage (NSLGC) for Airtel network within the period of signal strength measurement is 9, Glo network is 8, MTN is 8 and 9 mobile is 7 as shown in Table 3 .

Thus, Coverage Level for Airtel Network $=\frac{3}{12} \times 100 \%=25 \%$

Coverage Level for Glo Network $=\frac{4}{12} \times 100 \%=33 \%$

Coverage Level for MTN Network $=\frac{8}{12} \times 100 \%=67 \%$

Coverage Level of 9 mobile $=\frac{3}{12} \times 100 \%=25 \%$

The coverage level (in percentage) of Airtel, Glo, MTN, and 9mobile networks are $25 \%, 33 \%, 67 \%$, and $25 \%$ respectively.

The signal coverage level (in percentage) of Airtel, Glo, MTN, and 9mobile networks in Amaigbo, Uli, and Amasa all in the South-Eastern part of Nigeria are summarized in the table below:

Table 4. Summary of signal strength of Airtel, Glo, MTN, and 9mobile networks in Amaigbo, Uli and Amasa

\begin{tabular}{|l|c|c|c|c|}
\hline \multirow{2}{*}{$\begin{array}{l}\text { Town (Study } \\
\text { location) }\end{array}$} & \multicolumn{4}{|c|}{ Signal Coverage Level } \\
\cline { 2 - 5 } & Airtel & Glo & MTN & 9 mobile \\
\hline Amaigbo & 10 & 10 & 30 & 10 \\
\hline Uli & 69 & 62 & 62 & 62 \\
\hline Amasa & 25 & 33 & 67 & 25 \\
\hline
\end{tabular}

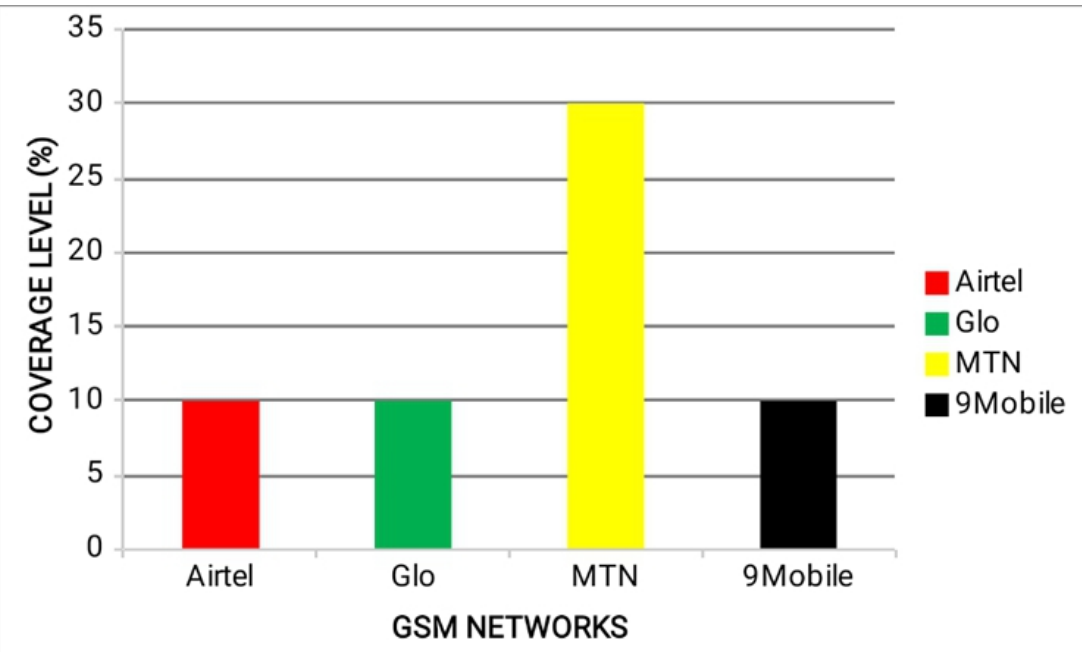

Figure 1. A chart showing the different GSM networks' coverage level in Amaigbo, Nwangele L.G.A., Imo State, South-East Nigeria from 18th August to 26th August 2018 


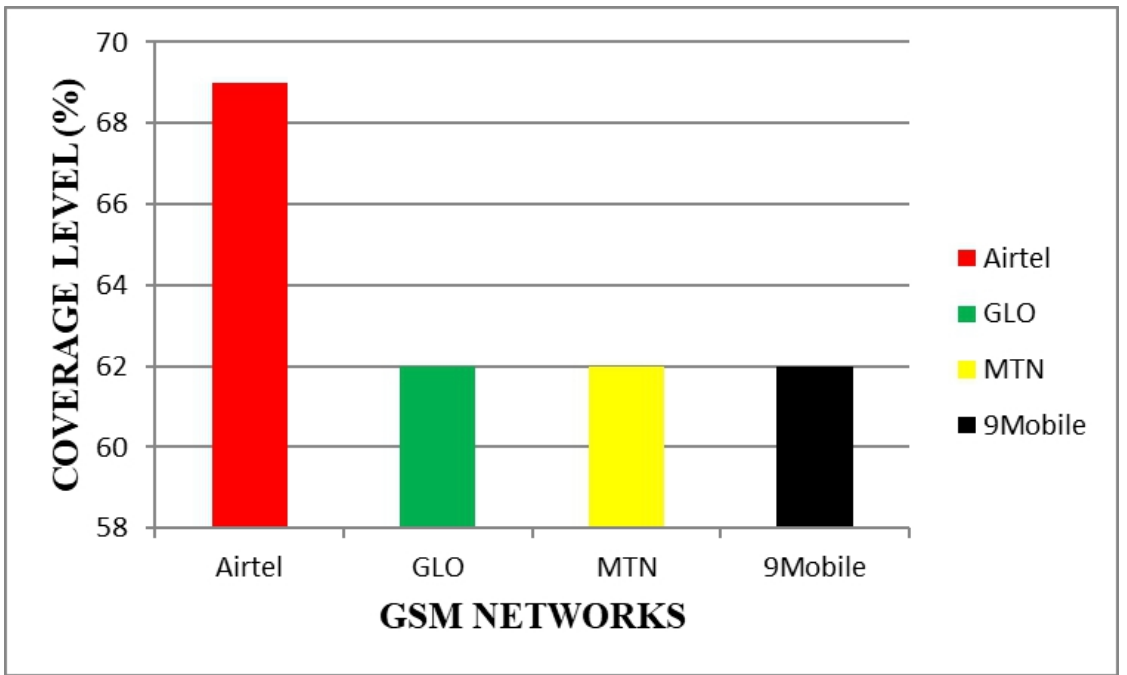

Figure 2. A chart showing the different GSM networks' coverage level in Uli, Ihiala L.G.A., Anambra State, South-East Nigeria from $29^{\text {th }}$ August to $6^{\text {th }}$ September 2018

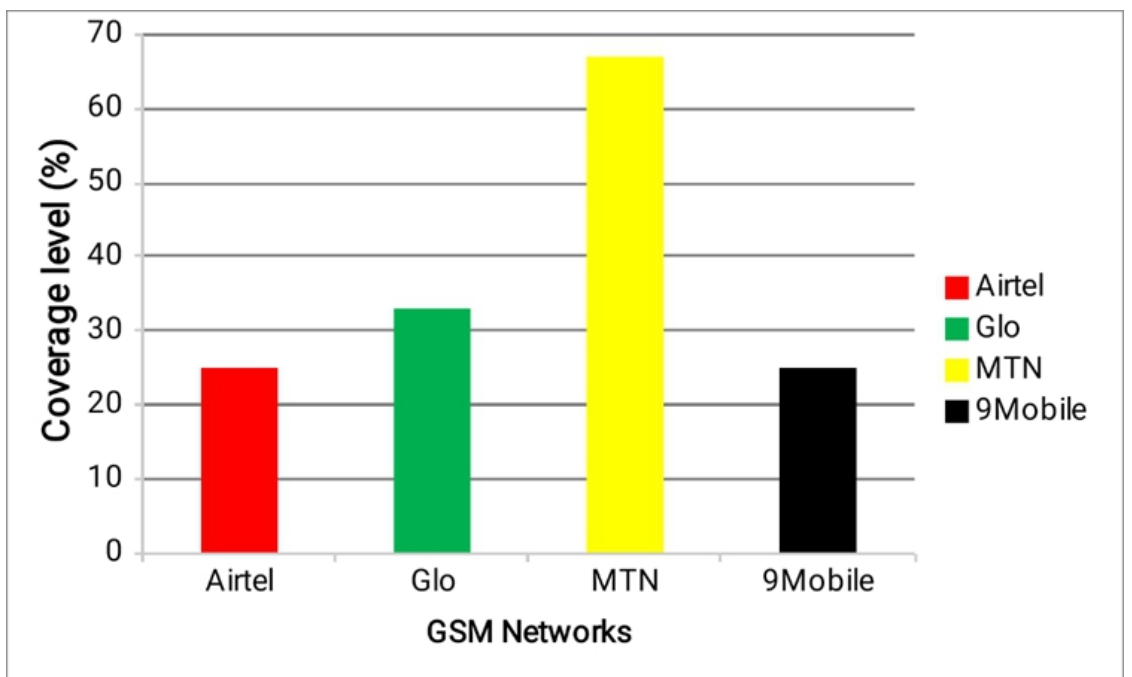

Figure 3. A chart showing the different GSM networks' coverage level in Amasa, Ohaofia L.G.A., Abia State, South-East Nigeria from $8^{\text {th }}$ to $16^{\text {th }}$ September 2018

It can be seen from Figure 2 that the GSM signal strength of the different networks studied in Amaigbo, Nwangele L.G.A. of Imo State, is comparatively very low. This is because of the location of the GSM network mast. The transmitting stations of most of these GSM networks are sited in Amandugba central market which is some distance away from Amaigbo, thus, leading to poor network in villages within Amaigbo. Previous studies carried out in Amaigbo shows that the people within the town receive little or no signal on their mobile phones, thus, making dissemination of information difficult. The result of the research shows that there is no significant difference 
between the different GSM networks studied as most of the networks are in a dead zone in some of the villages within Amaigbo where signal strength was measured.

The GSM signal strength of the various GSM networks in Uli, Ihiala L.G.A. of Imo State, Nigeria, is very Strong as shown in Figure 3. The signal strength of the different GSM networks studied in Uli ranges from $-55 \mathrm{dBm}$ to $-100 \mathrm{dBm}$ which is considered to be very strong for voice calls, SMS, and data sharing. The strong network is due to the central location of the transmitting stations of the different networks at Uli centre, School front, etc. The residents of Uli enjoys strong network services from all the available networks in the area thus making online business, telecommunication, and networking relatively cheap. Although there is no much difference in the coverage level of the different networks studied, Airtel network has a higher network coverage level of about $69 \%$ when compared to others with network coverage of about $62 \%$.

At Amasa in Ohaofia L.G.A. of Abia State, Nigeria, the signal strength of the various GSM networks studied was observed to be very low as presented in Figure 4. Thus, this resulted to poor network coverage level in villages within Amasa where signal strength measurement was carried out, except for MTN network which has a considerable good network coverage level in Amasa. The poor signal strength recorded is due to the lack of repeater stations in Amasa villages. More transmitting stations or installation of repeater stations at strategic places in Amasa would improve the quality of the signal strength received and thus increase the coverage levels of the various networks in Amasa.

\section{Conclusion}

The result of the study shows that most of the rural communities in the South- Eastern region of Nigeria experiences poor network coverage levels. The cause of the low network coverage level is due to poor signal strength received on mobile phones. Causes of poor signal strength in the studied areas ranges from physical factors such as obstruction by tall buildings and trees to transmission factors such as the distance of transmitting station, the height of transmitting antenna, and the numbers of repeater stations. Traffic congestion had no significant effect on the signal strength received from the transmitting station. It was observed from the investigation that signal strength of the different GSM networks studied is drastically poor at Amaigbo in Nwangele L.G.A. of Imo State and Amasa in Ohaofia L.G.A. of Abia state with the exception of MTN network which is relatively strong in Amasa. Although the signal strength of GSM network at Uli in Ihiala L.G.A. of Imo state is very strong, the quality of services provided by the different GSM networks provider generally needs improvement. 


\section{Recommendations}

From the result of this study, it is recommended that the network providers should site more booster stations in strategic places in rural communities within the South-East region of Nigeria to enhance signal strength received on mobile phones. Also, more research should be carried out in different locations in the villages where this study was carried out to find out the best locations to site the repeater stations. The GSM network providers are encouraged to ensure $100 \%$ network coverage with strong and reliable signal strength in the towns where signal strength was investigated in order to provide satisfactory service to their customers.

\section{References:}

1. Bablu, K.S., Heena, J., Aswathy, P. \& Komal, S. (2017). Comparative Analysis of Quality of Signal of Different Service Providers. International Journal of Innovative Research in Science, Engineering and Technology (IJIRSET). 6(4); 5629 - 5633.

2. Elechi, P., Orike, S., \& Musah, E.S. (2017). Determination of GSM Signal Lost in Multi-Partitioned Buildind. European Journal of Electrical and Computer Engineering (EJECE). 1(3); 4-11.

3. Elechi, P.E. \& Otasowie, P.O. (2015). Determination of GSM signal penetration loss in some selected buildings in Rivers State, Nigeria. Nigerian Journal of Technology (NIJOTECH). 34(3); $609-615$.

4. Emeruwa, C. (2015). Comparative Analysis of Signal Strengths of Some Cellular Networks in Umuahia Eastern Nigeria. Quest Journals. Journal of Electronics and Communication Engineering Research. 2(10); 01-05.

5. Iwuji, P.C. \& Emeruwa, C. (2018). Investigation of Signal StrengthLevel Generated by Orient 94.4 FM Transmitter in Imo State, Nigeria. International Journal of Science and Research (IJSR). 7(5); 1089 1094.

6. Kuboye, B.M., Alese, B.K., Fajuyigbe, O. \& Adewale, O. (2011). Development of Models for Managing Network Congestion on Global System for Mobile Communication (GSM) in Nigeria. Journal of Wireless Networking and Communications. 1(1): 8-15.

7. Ndukwe, E.C. (2006). Three years of GSM revolution in Nigeria. Nigerian Communications Commission (NCC). Pg 1-16.

8. Ndukwu, B.N., Onweremadu, E.U., Nkwopara, U.N., Ahukaemere, C.M., Ihem, E.E. \&

9. Agim, L.C. (2015). Variability of Selected Soil Properties of a River Slope in Amaigbo, Southeastern Nigeria. FUTO Journal Series (FUTOJNLS). 1(2); 8-16. 
10. Nkordeh, N., Olatunbosun, J. O., Bob-Manuel, I. \& Oni, O. (2016). Analysis of Mobile Networks Signal Strength for GSM Networks. Proceedings of the World Congress on Engineering and Computer Science (WCECS) San Francisco, USA. Vol I.

11. Olawole, M.O. (2013). Exploring Mobile Phone Uses and Rural Travel Behaviour in Ijesaland, Southwestern Nigeria. Ife Research Publications in Geography. 12(13); 29 - 44.

12. Oluwatoyin, K.K. (2015). Comparative Analysis of GSM and CDMA, Strength and Weakness, Future Challenges and Practical Solutions (A Case Study of MTN and NITEL Nigeria). Journal of Information Engineering and Applications. 5(5); $74-88$.

13. Omorogiuwa, O. (2015). Investigation of coverage level and the availability of GSM signal in Ekpoma, Nigeria. International Journal of Technical Research and Applications (IJTRA). 3(3); 350 - 355.

14. Onwuemele, A. (2011). Impact of mobile phones on rural livelihoods assets in rural Nigeria: A case study of ovia north east local government area. Nigerian Institute of Social and Economic Research (NISER) Social and Governance Policy Research Department. JORIND 9(2); 223-236.

15. Onyido, A.E., Obinatu, S.C., Umeanaeto, P.U., Obiukwu, M.O. \& Egbuche, M.C. (2011). Malaria Prevalence and Mosquito Vector Abundance in Uli Town, Ihiala Local Government Area, Anambra State, Nigeria. Africa Journal of Biomedical Research. 14(11); 175 182. 